Mr. Tremain begins by saying that the more we study recent developments in television, the more we are forced to realize that high-definition television is one of the outstanding scientific and engineering achievements of our time. In August 1936, the Alexandra Palace transmitter in north London was in full operation, giving the first public television service in the world. On May 12, 1937, the Coronation procession was televized with much success. It was the first outside television exhibition of importance. In conclusion, Mr. Tremain points out that television is destined to play in the future a leading part both as a means of communication and as a means of instruction. When planning for the future, it is important to bear this in mind. In England, as a result of pressure both from the cinema and radio industries, the experimental work being conducted for the purpose of extending the television service in the provinces was expedited. If a definite decision be taken with this end in view, we can look forward hopefully to it giving much direct employment in happier times.

\section{Standardizing Electric Distribution Cables}

Mr. S. W. Mexsom, of the staff of the Cable Makers' Association, has contributed a paper on the standardization of cables and equipment, with the object of reducing distribution costs, to the Electrical Review of June 7. Discussions have been going on for several years in order to frame an acceptable set of rules. The outbreak of war prevented the embodiment in the revised British Standard Specification for mains cables of the discussions during the last two or three years. The selection of standard sizes for cables to be used in a low-voltage network is a matter almost entirely for the supply engineers. It is difficult to forecast accurately the load which a distributor will have to carry, and since the data on which estimation has to be based are somewhat nebulous, there are strong reasons for the adoption of a few-possibly not more than two-standard sizes for a given system of low-voltage four-core cables.

Since the size of the undertaking and the loaddensity in the cable must vary between districts, it has been suggested that three sizes of four-core cable are required, namely, $0 \cdot 1,0.2$ and $0.3 \mathrm{sq}$. in., the smaller sizes being sufficient for the smaller systems and the larger for larger systems. Some suggest also that it would be more economical to use shaped and not circular conductors. The initial difficulties experienced in the construction of this type of cable have been overcome by the use of special apparatus. It is believed that the shaped conductor is quite as satisfactory as a circular conductor and is better technically. Difficulties have been experienced as to the best colours to use to identify the cores. The proposals that have been put forward envisage leaving the colours to the switchboard manufacturers and using numbers for the identification of cable cores. The questions of factor of safety and cost, now nearing solution, have involved a very large amount of work on the part of designers, research laboratories and testing authorities and great improvements are in immediate prospect.

\section{An Automatic Distress Signal}

THE Ministry of Shipping has given its approval to the 'Raft-o-Lite' safety flashing light of the International Marine Radio Co., Ltd., 63 Aldwych, W.C.2. It comprises a battery and light in a watertight case, provided with a float so that it will assume a vertical position when floating in the sea. A flasher is incorporated with it and this is designed to emit automatically the international distress signal 'S.O.S.'. When stored in an inverted or horizontal position the light is not in use, but when thrown into the water it assumes a vertical position and the flashing light is automatically switched on, continuing for forty-eight hours at least. The manufacturers point out that these lights are particularly suitable for oil-burning ships and tankers, where oil on the water may render dangerous the use of open flares.

\section{Breeding of Herbage Plants in Scandinavia and Finland}

Joint Publication No. 3, "The Breeding of Herbage Plants in Scandinavia and Finland" of the Imperial Agricultural Bureaux of Aberystwyth and Cambridge contains considerable information on the breeding of clovers and pasture grasses in Norway, Sweden, Denmark and Finland. The contributors are S. Nilsson-Leissner, F. Nilsson, E. Akerberg, R. Torssell, H. N. Frandsen, H. Wexelsen, and $O$. Pokjakalliv. A significant feature of the work in these countries is that the breeding work on a given crop has led to the country becoming independent of foreign seed for that crop. It was found, for example, that selection of late strains of red clover from local strains improved the yield by 10 per cent, and such selections are now so popular in Denmark that it is unnecessary to import seed. Similar results are reported from Norway and Sweden, where resistance to Sclerotinia trifoliorum and 'Tylenchus, 'persistance' and winter hardiness are of particular importance.

Both in red clover and timothy grass, inbreeding has been found to lead to drop in yield, vigour and fertility, while the 'hybrid corn method' of crossing inbred lines to produce heterosis is scarcely practicable. It is found preferable to adopt plant selection and cross breeding to give natural selection full scope. Frost hardiness is selected for by removing the snow from timothy plants. Alsike and white clover together with various species of Lolium, Festuca, Poa, Agrostis, Dactylis, Bromus and other genera are being bred for commercial work. The more important varieties which have been raised and a list of the many plantbreeding stations in Scandinavia which are given in this useful publication indicate the extent of the work in progress.

\section{Map of Antarctica}

THE Antaretic regions have been of official interest to Australia since 1933, when the Commonwealth Government announced its claim to a large sector of the continent south of the Indian Ocean between the Ross Dependency of New Zealand and Enderby Land. The Australian Antarctic Territory embraces about one quarter of the Antarctic regions. The 